\title{
The Swedish rare disease information database and the Swedish information centre for rare diseases
}

\author{
Christina Greek-Winald*, Birgitta Gustafsson, Lisbeth Högvik \\ From 5th European Conference on Rare Diseases (ECRD 2010) \\ Krakow, Poland. 13-15 May 2010
}

The Swedish National Board of Health and Welfare database of rare diseases contains detailed documents describing over 250 rare diseases, and new texts are constantly being produced. There are currently more than 500,000 Swedish and international visitors every year, and the figure is constantly rising. People with rare diseases and their families, parent and patient organisations, professionals, researchers and public authorities are all regular users. The database is freely and easily accessible to all at http://www.socialstyrelsen.se/ ovanligadiagnoser.

The Swedish Information Centre for Rare Diseases is the organisation commissioned by the Board of Health and Welfare to produce this material. The Information Centre is in regular contact with the most prominent Swedish specialists with expertise in rare diseases and works closely with them to produce the texts, ensuring that the documents are as clear and easy-to-read as possible. Patient and parent organisations supplement this information and a scientific advisory board reviews all documents before they are published. The texts are continually updated and revised. The information produced is available on-line but also in the form of printed pamphlets on specific diseases.

The Information Centre also serves as a helpline and a source of guidance to those directly or indirectly affected by rare diseases. It aims to increase awareness and understanding of these disorders not only by offering descriptions of the diseases, their symptoms, causes and treatment, but also by providing advice on habilitation, and information on relevant psychological, social and educational implications.

\footnotetext{
${ }^{*}$ Correspondence: christina.greek-winald@gu.se

The Swedish Information Centre for Rare Diseases, University of Gothenburg, The Sahlgrenska Academy, SE - 40530 Gothenburg, Sweden
}

The Swedish Information Centre for Rare Diseases is run under the auspices of the Sahlgrenska Academy at the University of Gothenburg. It is funded by the Swedish National Board of Health and Welfare.

Published: 19 October 2010

doi:10.1186/1750-1172-5-S1-O27

Cite this article as: Greek-Winald et al:: The Swedish rare disease information database and the Swedish information centre for rare diseases. Orphanet Journal of Rare Diseases 2010 5(Suppl 1):O27.

\section{Submit your next manuscript to BioMed Central and take full advantage of: \\ - Convenient online submission \\ - Thorough peer review \\ - No space constraints or color figure charges \\ - Immediate publication on acceptance \\ - Inclusion in PubMed, CAS, Scopus and Google Scholar \\ - Research which is freely available for redistribution \\ Submit your manuscript at www.biomedcentral.com/submit}

